\title{
Influence of Ethanolic Extracts of Spondias mombin (Anacardiaceae) Leaves on Pituitary- Gonadal Axis of Male Wistar Rats
}

\author{
O. R. Asuquo ${ }^{1,2, *}$, T. B. Ekanem ${ }^{1}$, O. O. K Oko ${ }^{3}$ and M. A. Eluwa ${ }^{1}$ \\ ${ }^{1}$ Department of Anatomical Sciences, Faculty of Basic Medical Sciences, University of Calabar, \\ PMB 1115, Calabar, Cross River State Nigeria. \\ ${ }^{2}$ Department of Human Anatomy, College of Medicine and Health Sciences, Afe Babalola University, \\ Ado-Ekiti, Ekiti State, Nigeria. \\ ${ }^{3}$ Department of Animal Sciences, Faculty of Agriculture, Forestry and Wildlife Resource Management, \\ University of Calabar, PMB 1115, Calabar, Cross River State, Nigeria.
}

\section{Authors' contributions}

This work was carried out in collaboration among all authors. Authors ORA and TBE designed the study, performed the statistical analysis, wrote the protocol. Authors ORA and OOKO wrote the first draft of the manuscript. Authors TBE, MAE and OOKO managed the analyses of the study. Authors

ORA, OOKO and MAE managed the literature searches. All authors read and approved the final manuscript.

\section{Article Information}

DOI: 10.9734/ARRB/2018/v30i630033 Editor(s):

(1) Prof. Xiao-Xin Yan, Department of Anatomy \& Neurobiology, Central South University Xiangya School of Medicine (CSUXYSM) 172 Tongzi Po Road, Changsha, Hunan 410013, China. Reviewers:

(1) Dr. George Perry, Dean and Professor of Biology, University of Texas at San Antonio, USA. (2) Egbe Ben Besong, University of Buea, Cameroon. (3) Jennifer R. Schroeder, Millikin University, USA. Complete Peer review History: http://www.sdiarticle3.com/review-history/46879

\section{ABSTRACT}

Background: Spondias mombin is one of the tropical plants used locally to treat various kinds of ailment, its use as an anti-conceptive remedy in our locality had been reported.

Objective: The aim of this study was to establish a dose-dependent or duration effect of ethanolic leaf extract of Spondias mombin on the anterior pituitary cells, testes and epididymides of Wistar rats of Wistar rats.

Materials and Methods: A total of thirty (30) matured male Wistar rats were randomly divided into five groups $(n=5)$. Group 1 animals served as control and received vehicle (distilled water). Groups 
2 and 3 were administered with $250 \mathrm{mgkg}^{-1}$ body weight of extract for 4 and 6 weeks respectively, while groups 4 and 5 received $500 \mathrm{mgkg}^{-1}$ body weight of extract for 4 and 6 weeks also. Animals were anaesthetized with chloroform and sacrificed at the end of the administration. Body weight, weights of reproductive organs and vital organs were evaluated. Blood was taken from the animals for haematological and biochemical analysis. The pituitary gland, male reproductive and accessory glands were excised and fixed in $10 \%$ formalin for routine histological examination.

Results: The influence of ethanolic extract of Spondias mombin leaves on the pituitary cells and reproductive organs of male Wistar rats given 250 and $500 \mathrm{mgkg}^{-1}$ body weight for 4 and 6 weeks showed loss of cytoplasmic contents and free spaces of pituitary cells, desquamation of seminiferous epithelial cells, degradation of seminiferous tubules and reduction in cells. The epididymis of the test groups showed abundant immature cells and cell debris in their lumen. The accessory glands showed homogenous pinkish fluid, glandular degeneration of the prostate and seminal vesicles with decreased structural integrity. The organ weights of the experimental animals were not significantly affected, however, a significant $(P<0.05)$ decrease in reproductive organ weights was recorded. Ethanolic extract of Spondias mombin on liver enzymes showed significant protection against hepatobiliary damage.

Conclusion: These results suggest that Spondias mombin has a dose-dependent and duration deleterious effect on the pituitary and reproductive organs at their cellular levels rather than on the tissue as a whole.

Keywords: Accessory glands; cells; degradation; epithelium; pituitary; reproduction.

\section{INTRODUCTION}

Medicinal plants still play major roles in health worldwide irrespective of the advances recorded in orthodox medicine. Interest in drugs derived from higher plants has increased considerably in the past few years with about $20-25 \%$ of modern drugs being derived from plants [1-2]. An expression in the biodiversity in number had been carried out with an estimate of 10-100 million species, out of which 2.5-7.5 million to be attributed to plants [3]; 5-105 of these plants have been scientifically evaluated for their therapeutic medicinal properties [4]. Plants have been used and are still in use in most developing countries as their main source of health care [5$6]$. These plants are assumed to be safe and free from side effects since they are naturally occurring [7-8]. However, studies have shown that medicinal plants may be toxic [9-12]. These adverse effects are however less frequent when used properly in comparison to synthetic medicines [13]. A lot of these herbal plants used to treat or cure diseases locally have been found to be anticancer [14-16], antimalarial [1718], anti-diabetic [19-20]' antihypertensive [2122], antibacterial [23], antimicrobial [24-25], antifertility [26-27], abortifacient [28-30] etc. These claims were first made by rural users which have been authenticated by biological research. Spondias mombin (SpM) is one of such plants used locally to treat various kinds of ailment which biological research has supported [31-37]. We had earlier reported on scientific findings on Spondias mombin [38-40]. The present study was carried out to further investigate the effect of Spondias mombin on pituitary cells and reproductive organs of male Wistar rats based on the duration of administration.

\section{MATERIALS AND METHODS}

The harvesting and extraction of plant material had earlier been reported in our previous work [40]. A total of thirty (30) mature male Wistar rats (6 weeks old) were randomly divided into five groups $(n=5)$. Rats were kept in a temperature controlled room of $25 \pm 2{ }^{\circ} \mathrm{C}$ with a 12-hour light/dark cycle under hygienic conditions and had free access to water \& rat chow. The animals were acclimatized for seven days before experimental use. Ethics on the use of laboratory animals was applied and care of the animals was in accordance with the International guidelines for animal research. The methodology was approved by the Department of Human Anatomy ethical committee. Group 1 animals served as control and received vehicle (distilled water). Groups 2 and 3 were administered $250 \mathrm{mgkg}^{-1}$ body weight of extract for 4 and 6 weeks respectively, while groups 4 and 5 received 500 $\mathrm{mgkg}^{-1}$ body weight of extract for 4 and 6 weeks also. The administration of extract was through oral route with the aid of an orogastric tube. Animals were anaesthetized with chloroform and sacrificed at the end of the administration. Body weight, weights of reproductive organs and vital 
organs were evaluated. Blood was taken from the animals for haematological and biochemical analysis. The pituitary gland, male reproductive and accessory glands were excised and fixed in $10 \%$ formalin and later processed for histological examination. The pituitary gland was double stained using the bromine alcian blue-orange fuschin green (Br.AB-OFG) method of Slidders [41] to demonstrate anterior pituitary cells. Data were expressed as Mean \pm S.E.M. Statistical analysis was carried out by one-way analysis of variance (ANOVA) with significance expressed as $\mathrm{P}<0.05$.

\section{RESULTS AND DISCUSSION}

The mean vital organs weight was not affected by the administration of leaf extract of SpM for 4 and 6 weeks (Table 1). However, the reproductive organ weights were significantly $(P<0.05)$ reduced at 6 weeks in animals administered with 250 and $500 \mathrm{mgkg}^{-1}$, irrespective of a non- significant change in body weights across the five groups (Table 2). The identification of the possible harmful effects of chemical and drugs is the analysis of organ weight [42]. In this study, the organ weights and body weights of the experimental groups were not different from that of the control which points to earlier findings of the safe use of SpM extracts [43]. However, reproductive organ weights were affected by an extract of SpM which is indicative of the shrunken characteristics observed on histopathological examination of the tissues. The red blood cell counts were increased significantly $(P<0.05)$ in groups 3 and 5 which received 250 and $500 \mathrm{mgkg}^{-1}$ for 6 weeks. Similarly, values for haemoglobin also significantly increased $(P<0.05)$ in these groups. Values of ALP reduced in groups 3 and 5 (Table 3). Enzymes have been reported to be found in tissues and blood as a result of insult to the cell or from degraded cells [44]. Activities of liver enzymes are determined in serum as indicators of biochemical changes which occur in response to treatment [45]. It had been stated that aminotransferases (ALT and AST) are indicators of hepatotoxicity and hepatocellular damage, while ALP is used in diagnosing hepatobiliary or cholestatic obstruction [46]. ALP is cardinally involved in the transport of metabolites across cell membranes, synthesis of proteins, secretory activities and glycogen metabolism [47]. The significant $(P<0.05)$ decrease observed in ALP activity may imply protection against hepatobiliary damage, since most enzymes measured as indices of drug metabolism are released into the bloodstream when cells are damaged or their functions are disrupted. Total protein (TP) levels did not show any significance although it increased amongst the experimental groups and control. Albumin (ALB) levels however significantly increased in the groups treated for 6 weeks as also recorded with creatinine (CRT) and urea. Proteins are important parts of all cells and tissues. Total protein test is carried out to diagnose nutritional problems and liver disease. In the experimental animals, a non-significant increase in total protein levels was observed, however, albumin was significantly increased at 6 weeks in both dosages in groups administered with $500 \mathrm{mgkg}^{-1}$ of extract. The increased protein albumin levels recorded in this study indicate a possible impairment in the normal function of the liver as established by Ahmad et al [48] that a change in the concentration of serum protein and albumin indicate a change in normal liver function. Creatinine and urea tests are carried out to evaluate the function of the kidney. In this study, creatinine and urea levels were significantly increased in groups treated for 6 weeks. Creatinine is the major kidney function parameter and its observed high level might be as a result of the decrease of synthesis or increase the functional capacity of tubular excretion [49].

Pituitary cells of control animals were well stained, normal and numerous on histological examination, whereas cells of experimental animals were sparse with loss of cytoplasmic contents. The effect was more in groups treated for 6 weeks recording greater loss of cytoplasmic contents and free spaces (Fig. 1a-e). The testes on histopathological examination showed seminiferous tubules of control possessing epithelia with well-defined Sertoli cells and germ cells at various stages of spermatogenesis. Sertoli cells showed distinct granular cytoplasm and irregular nuclei. Lumen of seminiferous tubules contained mature sperm and numerous Leydig cells in the interstitium (Fig. 2a). Groups 2-5 animals showed dose and time duration dependent alteration on the testes evidenced by distortion of tubular cells, prominent spaces and severe structural disorganization (Fig. 2b-e).

Epididymis of experimental groups showed thinness of epididymal epithelial lining compared to control with their lumen showing cell debris, large number of immature cells and degenerated cells (Fig. 3a-e). The lumen of the prostate of experimental animals showed pinkish fluid and inflammatory cells (Fig. 4a-e). The presence of 
debris in the lumen of the epididymis may be a reflection of degenerated testicular assault observed in the treated rats. This lesion may probably have been passed to the epididymis. Thus, it is safe to deduce that the extract of SpM has a defective effect on the germ cells. The observed effect of the extract on the accessory sex gland may also be as a result of its destructive tendency on testicular tissue that led to a decrease testosterone production [48]; since a decrease in testosterone production has been observed to have negating effect on accessory sex glands [50]. Therefore, it is safe to state that the low testosterone reported in our earlier work [51] may be responsible for the effect of the extract on the accessory sex glands since male accessory sex glands are known to depend on male sex hormone for development and secretory activity [52].

Table 1. Weight of vital organs of control and experimental SpM extract treated rats

\begin{tabular}{llllll}
\hline $\begin{array}{l}\text { Parameters } \\
\text { (g) }\end{array}$ & \multicolumn{5}{c}{ Groups } \\
\cline { 2 - 6 } & $\mathbf{1}$ & $\mathbf{2}$ & $\mathbf{3}$ & $\mathbf{4}$ & $\mathbf{5}$ \\
\hline Brain & $1.85 \pm 0.25$ & $1.82 \pm 0.05$ & $1.77 \pm 0.14$ & $1.73 \pm 0.23$ & $1.72 \pm 0.28$ \\
Heart & $0.82 \pm 0.05$ & $0.76 \pm 0.02$ & $0.72 \pm 0.03$ & $0.70 \pm 0.06$ & $0.68 \pm 0.24$ \\
Lungs & $1.56 \pm 0.30$ & $1.54 \pm 0.35$ & $1.48 \pm 0.20$ & $1.49 \pm 0.30$ & $1.46 \pm 0.28$ \\
Thyroid & $0.060 \pm 0.002$ & $0.060 \pm 0.002$ & $0.050 \pm 0.002$ & $0.048 \pm 0.006$ & $0.046 \pm 0.006$ \\
Kidney & $1.80 \pm 0.28$ & $1.78 \pm 0.22$ & $1.72 \pm 0.29$ & $1.70 \pm 0.20$ & $1.70 \pm 0.24$ \\
Liver & $8.26 \pm 0.80$ & $8.00 \pm 0.78$ & $7.95 \pm 0.80$ & $7.64 \pm 0.75$ & $7.62 \pm 0.82$ \\
Adrenal & $0.180 \pm 0.002$ & $0.178 \pm 0.002$ & $0.178 \pm 0.002$ & $0.176 \pm 0.002$ & $0.173 \pm 0.002$ \\
Spleen & $0.62 \pm 0.20$ & $0.60 \pm 0.27$ & $0.60 \pm 0.18$ & $0.58 \pm 0.22$ & $0.55 \pm 0.21$ \\
\hline
\end{tabular}

Values are Mean \pm SEM, $n=5$. The extract had no significant effect on the weights of vital organs

Table 2. Body and reproductive organ weights in control and treated rats

\begin{tabular}{llllll}
\hline Parameters (g) & \multicolumn{5}{c}{ Groups } \\
\cline { 2 - 6 } & $\mathbf{1}$ & $\mathbf{2}$ & $\mathbf{3}$ & $\mathbf{4}$ & $\mathbf{5}$ \\
\hline Body weight & $210 \pm 2.42$ & $208.7 \pm 3.42$ & $214.0 \pm 2.07$ & $204.5 \pm 3.57$ & $210.0 \pm 1.82$ \\
Testis & $3.20 \pm 0.75$ & $2.75 \pm 0.43$ & $1.43 \pm 0.36^{*}$ & $2.44 \pm 0.23^{*}$ & $1.26 \pm 0.15^{*}$ \\
Epididymis & $2.75 \pm 1.36$ & $2.55 \pm 1.80$ & $1.89 \pm 0.82^{*}$ & $2.24 \pm 1.08^{*}$ & $1.54 \pm 0.62^{*}$ \\
Seminal vesicle & $3.75 \pm 1.10$ & $2.92 \pm 0.34$ & $1.83 \pm 0.33^{*}$ & $1.72 \pm 0.64^{*}$ & $1.46 \pm 0.73^{*}$ \\
Prostate & $1.92 \pm 0.79$ & $1.63 \pm 0.64$ & $1.42 \pm 0.64^{*}$ & $1.26 \pm 0.48^{*}$ & $1.08 \pm 0.84^{*}$ \\
\hline \multicolumn{7}{l}{ Values are Mean $\pm S E M, n=5 .{ }^{*} P<0.05$ compared to control. The extract showed a significant effect on the } \\
weights of reproductive organs compared to body weights of animals where no significant effect was recorded
\end{tabular}

Table 3. Haematological and biochemical parameters of control and SpM extract treated rats. values are Mean $\pm S E M, n=5$. $P<0.05$

\begin{tabular}{|c|c|c|c|c|c|}
\hline \multirow[t]{2}{*}{ Parameters } & \multicolumn{4}{|c|}{ Groups } & \multirow[b]{2}{*}{5} \\
\hline & 1 & 2 & 3 & 4 & \\
\hline $\mathrm{RBC}\left(10^{4} / \mu \mathrm{L}\right)$ & $7.44 \pm 0,38$ & $7.93 \pm 0.22$ & $8.82 \pm 0.12^{*}$ & $8.72 \pm 0.10^{*}$ & $8.85 \pm 0.23^{*}$ \\
\hline $\operatorname{WBC}\left(10^{3} / \mu \mathrm{L}\right)$ & $19.58 \pm 3.50$ & $18.78 \pm 1.40$ & $16.64 \pm 2.10$ & $19.32 \pm 1.96$ & $18.42 \pm 2.46$ \\
\hline $\mathrm{HB}(\mathrm{g} / \mathrm{dL})$ & $11.68 \pm 0.59$ & $12.20 \pm 0.27$ & $15.42 \pm 0.21^{*}$ & $13.28 \pm 0.26^{*}$ & $18.38 \pm 1.05^{*}$ \\
\hline PCV (\%) & $45.78 \pm 2.64$ & $49.74 \pm 1.78$ & $47.16 \pm 0.62$ & $54.30 \pm 1.45^{\star}$ & $47.58 \pm 0.94$ \\
\hline $\operatorname{ALP}(\mu \mathrm{L})$ & $27.05 \pm 1.77$ & $17.70 \pm 0.36^{*}$ & $0.66 \pm 0.03^{*}$ & $12.96 \pm 1.06^{*}$ & $0.19 \pm 0.07^{*}$ \\
\hline AST $(\mu \mathrm{L})$ & $373.42 \pm 47.45$ & $294.88 \pm 17.07^{*}$ & $447.01 \pm 8.05^{\star}$ & $218.41 \pm 50.03^{*}$ & $442.67 \pm 14.75^{\star}$ \\
\hline $\operatorname{ALT}(\mu \mathrm{L})$ & $170.76 \pm 9.66$ & $154.15 \pm 6.31$ & $171.56 \pm 6.95$ & $151.78 \pm 4.17^{*}$ & $171.62 \pm 2.14$ \\
\hline $\mathrm{TP}(\mathrm{mg} / \mathrm{L})$ & $0.51 \pm 0.13$ & $0.40 \pm 0.06$ & $0.64 \pm 0.08$ & $0.27 \pm 0.03$ & $0.59 \pm 0.13$ \\
\hline ALB $(\mathrm{mg} / \mathrm{L})$ & $5.31 \pm 0.74$ & $3.90 \pm 1.58$ & $1.79 \pm 0.34^{*}$ & $2.73 \pm 0.93^{*}$ & $1.58 \pm 0.48^{*}$ \\
\hline CRT $(\mu \mathrm{mol} / \mathrm{l})$ & $2.06 \pm 0.28$ & $2.92 \pm 0.59$ & $2.77 \pm 0.79^{*}$ & $2.74 \pm 0.64$ & $3.95 \pm 0.73^{*}$ \\
\hline UREA (mg/L) & $32.08 \pm 0.93$ & $29.72 \pm 1.42$ & $16.03 \pm 0.71^{*}$ & $34.86 \pm 1.87$ & $14.50 \pm 3.83^{*}$ \\
\hline
\end{tabular}



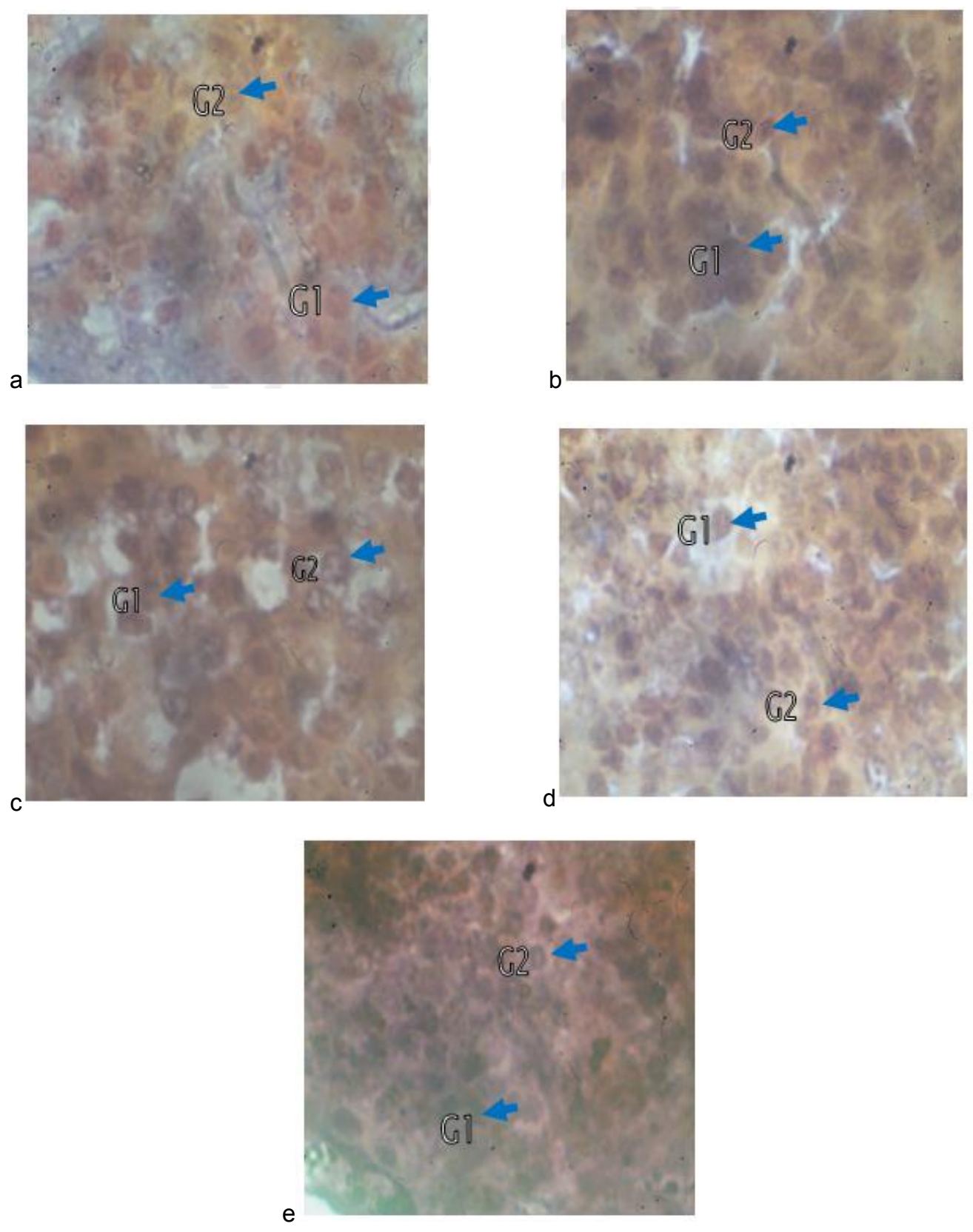

Fig. 1. Photomicrographs of anterior pituitary of control and experimental animals treated with $250 \mathrm{mgkg}^{-1}$ and $500 \mathrm{mgkg}^{-1}$ ethanolic extract for 4 and 6 weeks (Br. AB/OFG X 400)

a. Anterior pituitary of control showing normal gonadotrophs $F S H\left(G_{1}\right)$ and $L H\left(G_{2}\right)$ respectively.

b. Anterior pituitary of $250 \mathrm{mg} / \mathrm{kg}$ ethanol extract treated for 4 weeks showing hypertrophied gonadotrophs FSH $\left(G_{1}\right)$ and $L H\left(G_{2}\right)$.

c. Anterior pituitary of $250 \mathrm{mg} / \mathrm{kg}$ ethanol extract treated for 6 weeks showing regressed gonadotrophs FSH $\left(G_{1}\right)$ and $L H\left(G_{2}\right)$.

d. Anterior pituitary of $500 \mathrm{mg} / \mathrm{kg}$ ethanol extract treated for 4 weeks showing hypertrophied gonadotrophs FSH $\left(G_{1}\right)$ and $L H\left(G_{2}\right)$.

e. Anterior pituitary of $500 \mathrm{mg} / \mathrm{kg}$ ethanol extract treated for 6 weeks showing regressed gonadotrophs $F S H\left(G_{1}\right)$ and $L H\left(G_{2}\right)$ with loss of cytoplasmic contents. 

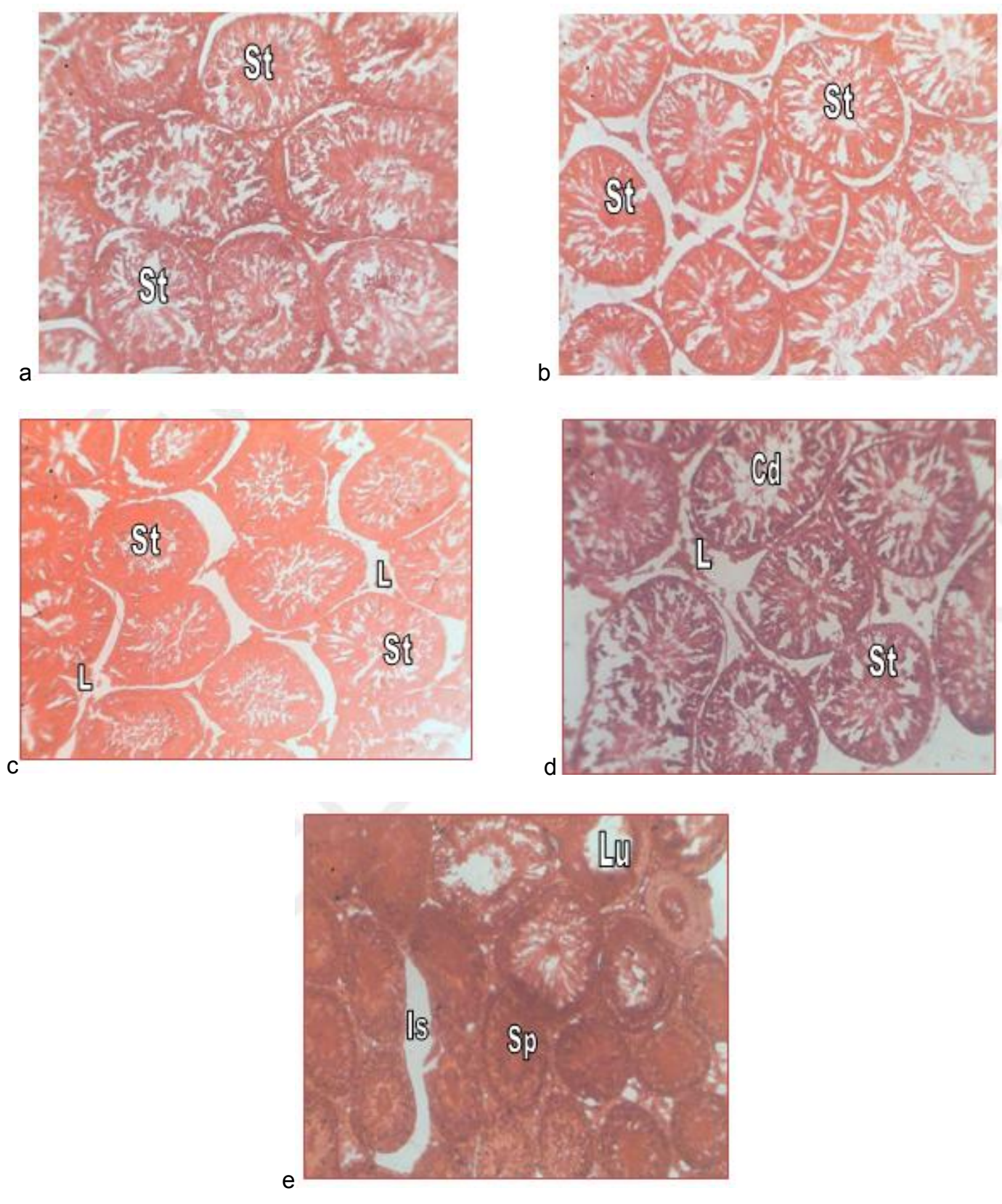

Fig. 2. Photomicrographs of testis of control and experimental animals treated with $250 \mathrm{mgkg}^{-1}$ and $500 \mathrm{mgkg}^{-1}$ ethanolic extract for 4 and 6 weeks (H \& E X 400)

a. Testis of control animal showing well arranged seminiferous tubules (St) and normal process of spermatogenesis.

b. Testis of $250 \mathrm{mg} / \mathrm{kg}$ ethanol extract treated for 4 weeks showing loosely arranged seminiferous tubules (St).

c. Testis of $250 \mathrm{mg} / \mathrm{kg}$ ethanol extract treated for 6 weeks showing shrunken seminiferous tubules (St) and loss of Leydig cells (L).

d. Testis of $500 \mathrm{mg} / \mathrm{kg}$ ethanol extract treated for 4 weeks showing distorted seminiferous tubules (St), loss of Leydig cells (L) and cell debris (Cd).

e. Testis of $500 \mathrm{mg} / \mathrm{kg}$ ethanol extract treated for 6 weeks showing arrest of spermatogenesis (Sp), empty lumen (Lu) and loss of interstitial tissue (Is). 

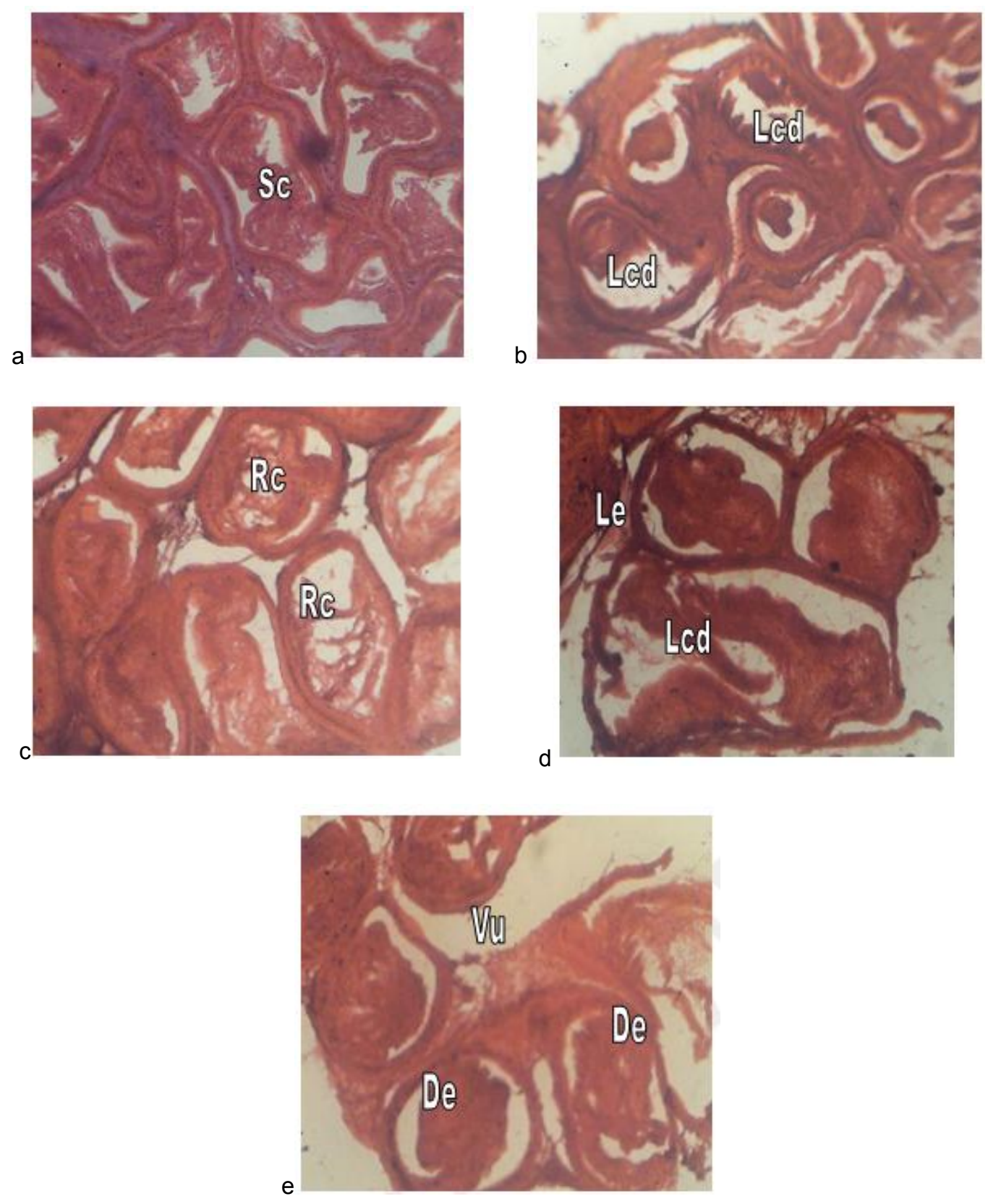

Fig. 3. Photomicrographs of epididymis of control and experimental animals treated with $250 \mathrm{mgkg}^{-1}$ and $500 \mathrm{mgkg}^{-1}$ ethanolic extract for 4 and 6 weeks (H \& E X 400)

a. Epididymis of control animal showing tubules filled with sperm cells (Sc).

b. Epididymis of $250 \mathrm{mg} / \mathrm{kg}$ ethanol extract treated for 4 weeks showing lumen containing cell debris (Lcd).

c. Epididymis of $250 \mathrm{mg} / \mathrm{kg}$ ethanol extract treated for 6 weeks showing regressive changes (Rc).

d. Epididymis of $500 \mathrm{mg} / \mathrm{kg}$ ethanol extract treated for 4 weeks showing loss epithelium (Le) and cell debris (Lcd) in lumen.

e. Epididymis of $500 \mathrm{mg} / \mathrm{kg}$ ethanol extract treated for 6 weeks showing distortion of epididymal tissue (De) and presence of vacuoles $(\mathrm{Vu})$. 

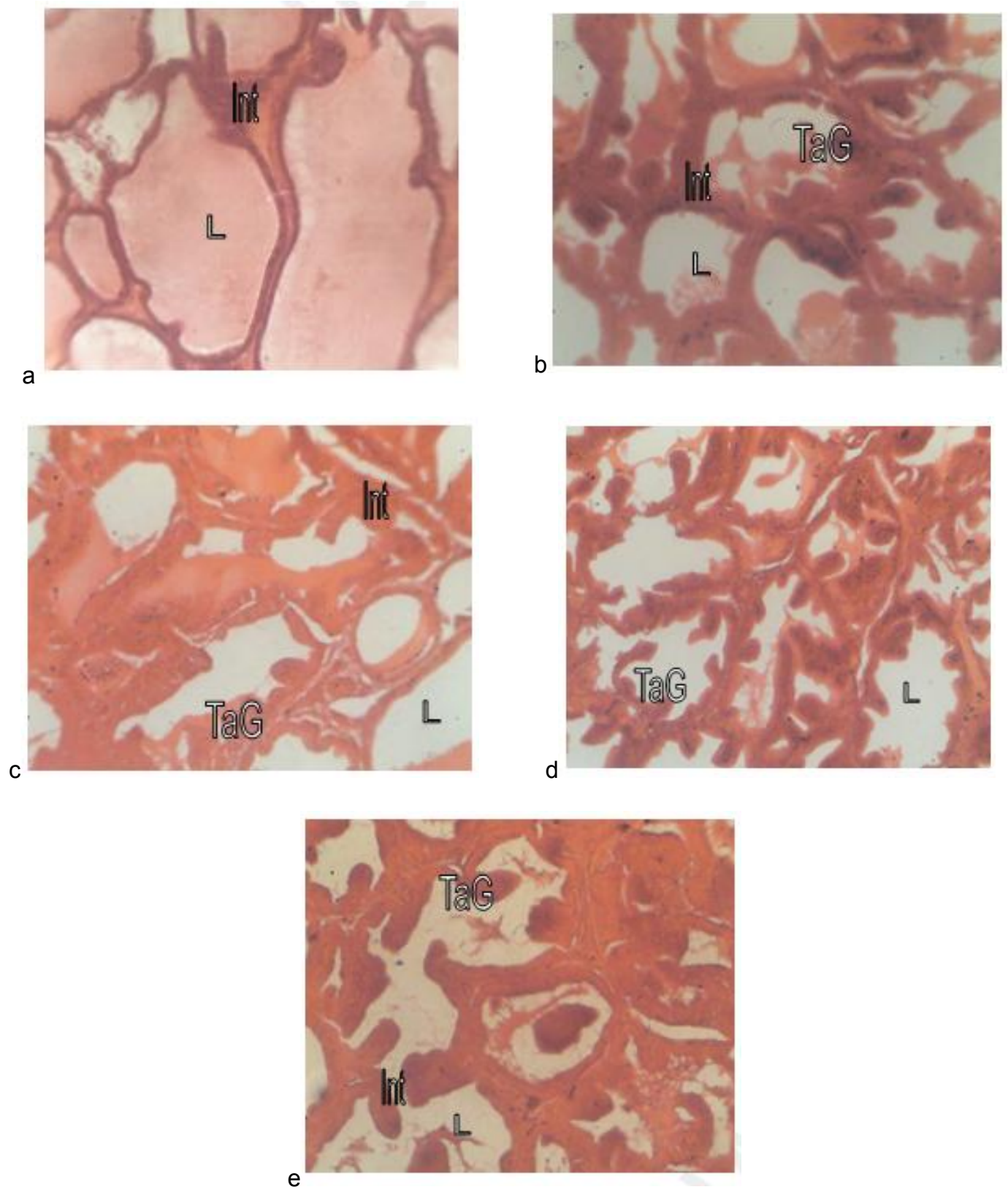

Fig. 4. Photomicrographs of prostate gland of control and experimental animals treated with $250 \mathrm{mgkg}^{-1}$ and $500 \mathrm{mgkg}^{-1}$ ethanolic extract for 4 and 6 weeks (H \& E X 400)

a. Prostate of control animal showing normal architecture with well defined interstitial tissue (Int) and lumen (L) filled with prostatic secretions.

b. Prostate of $250 \mathrm{mg} / \mathrm{kg}$ ethanol extract treated for 4 weeks showing lumen (L) with less secretions, thinned out interstitial tissue (Int) and tubuloalveolar glands (TaG) .

c. Prostate of $250 \mathrm{mg} / \mathrm{kg}$ ethanol extract treated for 6 weeks showing regressive changes in cytoarchitecture.

d. Prostate of $500 \mathrm{mg} / \mathrm{kg}$ ethanol extract treated for 4 weeks showing changes in the shape of glands (TaG), wider and empty lumen (L).

e. Prostate of $500 \mathrm{mg} / \mathrm{kg}$ ethanol extract treated for 6 weeks showing distortions of gland (TaG), lumen (L) and interstitial tissue (Int). 


\section{CONCLUSION}

This study concludes that the effect of an extract of SpM is dose and duration dependent with its effect localized to the pituitary and male reproductive system which supports its use locally to stall conception in the male. The mechanism through which this is mediated is not known. Further research will be based on the mechanism through which SpM mediate this action.

\section{ETHICAL APPROVAL}

Approval was given by the Faculty of Basic Medical Sciences Committee on animal use and care, Universiity of Calabar to carry out this research work following laid down rules and guidelines of the institution in the use of medicinal plants and animal models.

\section{COMPETING INTERESTS}

Authors have declared that no competing interests exist.

\section{REFERENCES}

1. Veeresham C. Natural products derived from plants as a source of drugs. J Adv Pharm Technol Res. 2012;3(4):200-207.

2. Newman DJ, Cragg GM, Snader KM. The influence of natural products upon drug discovery. Nat Prod Reports. 2000;17: 215-234.

3. Pimm SL, Russell GJ. Gittlemqn JL, Brooks TM. The future of biodiversity. Science 1995;5:347-350.

4. Verpoorte R. Exploration of nature's chemodiversity: The role of secondary metabolites as lead drugs for drug development. Drug Dev Today. 1998;3: 232-238.

5. Kumar S, Kumar R, Khan A. Medicinal plant resources: Manifestation and prospects of life-sustaining healthcare system. Cont J Biol Sci. 2001;4(1):19-29.

6. Sathiyaraj $K$, Sivaraj $A$, Thirumalai $T$, Senthil Kumar B. Ethnobotanical study of antifertility medicinal plants used by the local people in Kathiyavadi village, Vellore District, Tamilnadu, India. Asian Pac J Trop Biomed. 2012;S1285-S1288.

7. Haq I. Safety of medicinal plants. Pak J Med Res. 2004;43(4):203-210.

8. Nasri H, Shirzad H. Toxicity and safety of medicinal plants. J Herb Med Pharmacol. 2013;2(2):21-22.
9. Cupp MJ. Toxicology and chemical pharmacology of herbal products. Totowa, NJ: Humaila Press; 2000.

10. Boullata JI, Nace AM. Safety issues with herbal medicine. Pharmacotherapy. 2000; 20(3):257-269.

11. Posadzki P, Watson LK, Ernst E. Adverse effect of herbal medicines: An overview of systematic review. Clin Med. 2013;13(1): 7-12.

12. Hussin AHJ. Adverse effects of herbs and drug-herbal interactions. Malaysian $\mathrm{J}$ Pharm. 2001;1(2):39-44.

13. Calixto JB. Efficacy, safety, quality control marketing and regulatory guidelines for herbal medicines (phytotherapeutic agents). Brazilian J Med Biol Res. 2000; 33:179-189.

14. Cragg GM, Newman DJ. Plants as a source of anti-cancer agents. J Ethnopharm. 2005;100(1-2):72-79.

15. Soladoye MO, Amusa VA, RAji-Esan SO, Chukuma EC, Ayanbamiji AT. Ethnobotanical survey of anti-cancer plants in Ogun State, Nigeria. Annals Biol Res. 2010;1(4):261-273.

16. Mohan S, Bustamam A, Ibrahim S, AlZubain AS, Aspollah M. Anti-cancerous effect of Tryphonium flagelliforme on human T4-lymphoblastoid cell line CEMSS. J Pharm Toxicol. 2008;3(6):449-456.

17. Adebayo JO, Krettlu AO. Potential antimalarials from Nigerian plants: A review. J Ethnopharmacol. 2011;133:289-302.

18. Okpako LC, Ajsiyebo EO. In vitro and in vivo anti-malarial activities of Striga hermonthiacca and Tapinanthus sessifolius extracts. Afr J Med Sci. 2004;1: 73-75.

19. Ezekwesili $\mathrm{CN}$, Ogbunugafor $\mathrm{HA}$, Ezekwesili-Ofili JO. Anti-diabetic activity of aqueous extracts of Vites doniana leaves and Cinchona calisaya bark in alloxan induced diabetic rats. Int J Trop Dis Health. 2012;2(4):290-300.

20. Chauhan A, Sharma PK, Srivastava $P$, Kumar N, Dudhe R. Plants having potential anti-diabetic activity: A review. Der Pharmacie Lettre. 2010;2(3):369-387.

21. Patel SS, Verma NK, Ravi VG, Authaman $\mathrm{K}$, Soni N. Anti-hypertensive effect of an aqueous extract of Passiflora nepalensis wall. Int J Appl Res Nat Prod. 2010;3(2): 22-27.

22. Iwalokun BA, Hodonu SA, Nwoke S, Ojo $\mathrm{O}$, Agomo PU. Evaluation of the possible mechanisms of anti-hypertensive activity of 
Loranthus micranthus: African mistletoe. Biochem Res Int. 2011;11:1-9.

23. Ekundayo EO, Ekekwe JN. Antibacterial activity of leaf extracts of Jatropha curcas and Euphorbia heterophylla. Afr J Microbiol Res. 2013;7(44):5097-5100.

24. Oliveira AA, Segovia JFO, Sousa VYK, Mata ECG, Gonçalves MCA, Bezerra RM, Jumor POM, Kanzaki LIB. Anti-microbial activity of Amazonian medicinal plants. Biomed Life Sci. 2013;2:371-376.

25. Aladesanmi AJ, Iwalewa EO, Adebajo AC, Akinkunmi EO, TAiwo BJ, Olorunmola FO, Lamikanra A. Anti-microbial and antioxidant activities of some Nigerian medicinal plants. Afr J Trad Comp Alt Med. 2007;4(2):173-184.

26. Raj A, Singh A, Sharma A, Singh N, Kumar $P$, Bhatia V. Antifertility activity of medicinal plants on reproductive system of female rat. Int J Bio-Eng Sci Tech. 2011;2(3):4450.

27. Joshi SC, Sharma A, Chaturvedi M. Antifertility potential of some medicinal plants in males: An overview. Int J Pharm Pharmaceut Sci. 2011;3(5):204-217.

28. Akah PA. Abortifacient activity of some Nigerian medicinal plants. Phytother Res. 1994;8(2):106-108.

29. Sethi N, Nath D, Shukla Sc, Dyal R. Abortifacient activity of a medicinal plant Moringa olifera in rats. Ancient Sci Life. 1988;7(3-4):172-174.

30. Yakubu MT, Bukoye BB. Abortifacient potentials of the aqueous extract of Bambusa vulgaris leaves in pregnant Dutch rabbits. Contraception. 2009; 80(2009):308-313.

31. Ayoka AO, Akomolafe RO, Iwalewa EO, Ukponmwan OE. Studies on the anxiolytic effect of Spondias mombin L (Anacardiaceae) extracts. Afr J Trad Compl Alt Med. 2005;2(2):153-165.

32. Ajao AO, Shonukan O, Femi-Onadeko B. Anti-bacterial effect of aqueous and alcohol extracts of Spondias mombin and Alchonea cordifolia: Two local antimicrobial remedies. Int J Crude Drug Res 1985;23: 67-72.

33. Iweala EEJ, Oludare FD. Hypoglycaemic effect, biochemical and histological changes of Spondias mombin and Parinari polyandra Benth Seeds ethanolic extracts in alloxan induced diabetic rats. J Pharm Toxicol. 2011;6(2):101-112.

34. Uchendu CN, Isek T. Antifertility activity of aqueous ethanolic extract of Spondias mombin (Anacardiaceae) in rats. Afr Health Sci. 2008;8(3):163-167.

35. Abo KA, Ogunleye VO, Asindi JS. Antimicrobial potential of Spondias mombin, Croton zambesicus and Zygotritonia crocea. Phytother Res. 1999; 13:494-497.

36. Corthout J, Pieters LA, Claeys M, VandenBerghe DA, Viletinck AJ. Antibacterial and molluscicidal phenolic acid from Spondias mombin. Planta Med. 1994;60:460-463.

37. Goncalves JL, Lopez RC, Oliviera DB, Costa SS, Miranda MM, Romanos MT, Santos NS, Wigg MD. In vitro antirotavirus activity of some medicinal plants used in Brazil against diarrhea. J Ethnopharmacol. 2005;99(3):403-407.

38. Asuquo OR, Udonwa UN, Eluwa MA, Ekanem TB. Effects of Spondias mombin leaf extract on the cytoarchitecture of the cerebral cortex and on learning and memory in Wistar rats. Int J Sci Res. 2013; 2(9):5-8.

39. Asuquo OR, Ekanem TB, Udoh PB, Mesembe OE, Ebong PE. Haematinic potential of Spondias mombin leaf extract in Wistar rats. Adv Biores. 2013;4(2):5356.

40. Asuquo OR, Fischer CE, Mesembe OE, Igiri AO, Ekom IJ. Comparative study of aqueous and ethanolic leaf extracts of Spondias mombin on neurobehaviour in male rats. IOSR J Pharm Biol Scis. 2013; 5(2):29-35.

41. Slidders W. The OFG and BrAB-OFG methods for staining the adenohypohysis. J Path Bacteriol. 1961;82:532-534.

42. Bailey SA, Zidell RH, Perry RW. Relationship between organ weight and body/brain weight in the rat: What is the best analytical endpoint? Toxicol Pathol. 2004;32:448-466.

43. Asuquo OR, Ekanem TB, Eluwa MA, Oko OO, Ikpi DE. Evaluation of toxicological effects of Spondias mombin in adult male Wistar rats. J Nat Sci Res. 2012;2(7):144151.

44. Hurtuk BL, Krefetz RG. Enzymes: In Bishop MC, Duben-Engel Kirk JL, Fody EP (Eds). Clinical chemistry, principles, procedures and correlations $\left(2^{\text {nd }} E d\right)$. Philadelphia, JB Lippincott Company. 1992;215-233.

45. Akpanabiatu MI, Umoh IB, Eyong EU, Udoh FV. Influence of Nauclea latifolia leaf extracts on some hepatic enzymes of rats 
fed on coconut oil and non-coconut oil meals. Pharm Biol. 2005;43(2):153-157.

46. Johnson DF, Fody EP. Liver function: In Bishop MC, Duben-Engel Kirk JL, Fody EP (Eds). Clinical chemistry, principles, procedures and correlations $\left(2^{\text {nd }} \mathrm{Ed}\right)$. Philadelphia, JB Lippincott Company. 1992;473-478.

47. Sharma A, Mathur R, Skukla S. Hepatoprotective action of a proprietary herbal preparation against carbon tetrachloride intoxication. Indian Drugs. 1995;32:120-124.

48. Ahmed M, Saeed MA, Alam H, Ashgar Z. Biological studies of indigenous medicinal plants II: Effects of Aplotaxis lappa Dcne on various parameters of liver metabolism in rabbits. J. IsI Acad Sci. 1992;5:51-56.
49. Zilva JF, Panmall PR, Mayne PD. Clinical chemistry in diagnosis and treatment. $5^{\text {th }}$ Ed, England; Clays Ltd, St Ives Plc., England.

50. Asuquo OR, Ekanem TB, Udoh PB, Eluwa MA, Mesembe OE. Antigonadotrophic effect of Spondias mombin extract in adult male Wistar rats. J Biol Agric Healthcare. 2012;2(7):14-17.

51. Kumara $M$, Singh $P$. Study of the reproductive organs and fertility of the male mice following administration of metronidazole. Int J Fert Sterl. 2013;7(3): 225-238.

52. Desjardins C. Endocrine regulation of reproductive development and function in the male. J Ani Sci. 1978;47:56-79.

(c) 2018 Asuquo et al.; This is an Open Access article distributed under the terms of the Creative Commons Attribution License (http://creativecommons.org/licenses/by/4.0), which permits unrestricted use, distribution, and reproduction in any medium, provided the original work is properly cited.

Peer-review history:

The peer review history for this paper can be accessed here: http://www.sdiarticle3.com/review-history/46879 